\title{
Growth response, nutrient digestibility and physical body measurements of Grasscutter (Thryonomys swinderianus) fed whole cassava (Manihot esculenta) root meal fortified with selected fermented protein sources
}

\author{
O. O. Eniolorunda, H. A. Awojobi, A. F. Aluko and B. S. Olufemi
}

Department of Animal Production, Faculty of Agricultural Production and Renewable Resource, College of Agricultural Sciences, Olabisi Onabanjo University, Ayetoro Campus, Ayetoro, Ogun State, Nigeria

\begin{tabular}{|c|c|}
\hline ARTICLE INFO & Abstract \\
\hline $\begin{array}{l}\text { Article history: } \\
\text { Received: } 21 \text { February } 2018 \\
\text { Accepted: } 06 \text { August } 2018\end{array}$ & $\begin{array}{l}\text { Grasscutter serves as a major tool for improved household income generation, nutrition and bio-diversity } \\
\text { in Nigeria. It provides a quick turnover, foreign exchange earner and reduce unemployment rate of the } \\
\text { country.In order to assess the feeding values of concentrates used as supplement, studies were conducted } \\
\text { in captivity to evaluate the performance of Grasscutter (Thryonomys swinderianus) using } 20 \text { growing }\end{array}$ \\
\hline $\begin{array}{l}\text { Keywords: } \\
\text { Cassava root, fermented protein, } \\
\text { Grasscutter, production } \\
\text { performance, captivity }\end{array}$ & $\begin{array}{l}\text { Grasscutters comprising } 16 \text { females and } 4 \text { males who were balanced for weight and grouped into four } \\
\text { treatments. Inclusion of whole cassava meal that was incorporated at } 80 \% \text { of the total bulk acted as the } \\
\text { control }\left(T_{0}\right) \text { while } 10 \% \text { of whole cassava root meal was replaced by fermented soybean meal in }\left(T_{1}\right) \text {, } \\
\text { fermented locust bean meal in }\left(T_{2}\right) \text { and fermented melon seed meal in }\left(T_{3}\right) \text { respectively were considered } \\
\text { as experimental using a complete randomized design. Elephant grass (Pennisetum purpureum) was used }\end{array}$ \\
\hline $\begin{array}{l}\text { Correspondence: } \\
\text { O. O. Eniolorunda } \\
\text { (olueniolorunda@gmail.com) }\end{array}$ & $\begin{array}{l}\text { as the basal diet and water were given ad libitum. There were significant difference in the final body } \\
\text { weight gains }(P<0.05) \text { between treatments. The mean final body weights were } 1175.0 \pm 302.01 \text {, } \\
1266.7 \pm 302.01,1215 \pm 302.01 \text { and } 1143.0 \pm 302.01 \mathrm{~g} \text { for animals on } \mathrm{T}_{0}, \mathrm{~T}_{1}, \mathrm{~T}_{2} \text { and } \mathrm{T}_{3} \text { respectively. The } \\
\text { corresponding mean for final body weight gains were found to be } 481 \pm 209.55,536.7 \pm 209.55,507 \pm 209.55 \\
\text { and } 407 \pm 209.55 \mathrm{~g} \text { for } \mathrm{T}_{0}, \mathrm{~T}_{1}, \mathrm{~T}_{2} \text { and } \mathrm{T}_{3} \text { respectively. There were significant differences }(\mathrm{P}<0.05) \text { in the } \\
\text { trunk length in } \mathrm{T}_{1} \text { over } \mathrm{T}_{2}, \mathrm{~T}_{0} \text { and } \mathrm{T}_{3} \text { and were recorded at the level of } 4.78 \pm 0.19,4.56 \pm 0.18,4.55 \pm 0.18 \\
\text { and } 4.12 \pm 0.16 \text { respectively. The nutrient digestibility of } \mathrm{CP} \text {, EE, NFE, ADF and ADL were significantly } \\
\text { different }(\mathrm{P}<0.05) \text {. The whole cassava root that was combined with fermented soybean meal supported a } \\
\text { highest growth rate than those of other treatments. It was therefore concluded that fermented soybean } \\
\text { meal may be used as an ideal diet for sustainable Grasscutter production when whole cassava root is } \\
\text { combined with this ingredient. }\end{array}$ \\
\hline
\end{tabular}

\section{Introduction}

The Grasscutter (Thryonomys swinderianus) production serves as a major tool for improved household income generation, nutrition and bio-diversit. It provides a quick turnover; serves as a foreign exchange earner; helps reduce unemployment rate of the country; additionally, it provides employment avenues for the physically challenged and people suffering from HIV/AIDS. Environmentally, Grasscutter rearing is very friendly. It helps to meet the demand for the supply of bush meat without undue pressure on the environment in many rural areas of Nigeria and other West African countries like Benin, Ghana, Togo and Ivory Coast. Grasscutter meat is greatly appreciated for its tenderness and taste and is an important source of animal protein in Ghana and the rest of West Africa. The meat is appreciated because of its culinary properties with high protein, calcium, phosphorous and moisture contents (Rahman et al., 2015; Rahman et al., 2016).

In Nigeria there is a diverse wildlife resource capable of supporting the protein intake of animal origin. Nonetheless in recent years, there had been significant shortfall between the production and supply of animal protein to feed the ever increasing population (Akpan, et. al., 2009) in Nigeria. Thus, in order to improve and foster the protein intake, efforts had been directed towards boosting the micro livestock sector and with an ever increasing demand,-there is a consistent and sustained outstripping of supply (National Research Council, 1991; Anon., 1993).

The grasscutter is primarily an herbivore animal in which major part of its diet is composed of grasses with fairly high crude fibre content (Schrage and Yewandan, 1995; Adu, 2005). It can apparently tolerate a certain level of tannin found in leaves and bark as well as cyanogenic glycosides present in green maize, sorghum and Manihotspp. and other agro-products (Ewer, 1969; Obi et.al.,2009; Eniolorunda and Olamilusi, 2016). However, the nutritional status of Grasscutter has been reported to be improved through the provision of pelleted concentrate for supplementary feeding especially when they are reared in captivity (Ayodele and Meduna, 2007). Good carcass quality and highest live weight were reported by Henry and Njume, (2008), when Grasscutters were fed with a metabolizable energy of $2000 \mathrm{Kcal} / \mathrm{kg}$ - in combination with chopped elephant 
grass (Pennisetum purpureum). Feeds containing 12$20 \%$ crude protein have been reported to be suitable for Grasscutter (Meduna, 2002) while 18\% crude protein (CP) was required for optimum growth of Grasscutter from weaning to reproductive age (Kusi, 2012).

Fermented foods have a long tradition and historically have been produced in order to extend the shelf life of raw material and increase their safety. In their production, micro-organisms plays vital and essential role contributing to the improvement of the physiochemical, sensory and safety characteristics of the final products (Cocolin and Ercolini, 2009). In addition, the fermentation is usually carried out in a moist solid state, involving contact with appropriate inocula of assorted microorganisms and is accomplished by the natural temperatures of the tropics. Therefore, the aim of this study was to determine the feed efficiency on growth response, nutrient digestibility and physical body measurement of growing Grasscutter fed cassava root meal and fortified with selected protein sources.

\section{Materials and Methods}

\section{Study location}

The study was carried out at the Grasscutter housing unit of the college of Agricultural Sciences, Olabisi Onabanjo University, Yewa campus, Ayetoro. Ayetoro is located in latitude $7^{0} 15^{1} \mathrm{~N}$ and longitude $3^{0} 3^{1} \mathrm{E}$ indeciduous derived savannah zone of Ogun State. Climate is sub humid tropical with an annual rainfall of $763.3 \mathrm{~mm}$ in 74days. Maximum temperature varies between $29^{\circ} \mathrm{C}$ during the peak of wet season (Feb and March) and $34^{\circ} \mathrm{C}$ during the dry season, mean annual relative humidity is81\% (Onakomaya et al., 1992).

\section{Housing and Animal Management}

The experimental animals were housed in cages in a long tier metal cage supported at the base with strong iron rods such that the cage were raised to $45 \mathrm{~cm}$ from the floor level (the dimension of each cage was $60 \mathrm{~cm} \mathrm{x}$ $50 \mathrm{~cm} \times 40 \mathrm{~cm}$ ). The cages were placed inside a wellventilated and naturally illuminated Animal Nutrition Laboratory in the College of Agricultural Sciences at the Olabisi Onabanjo University, Yewa Campus, Ayetoro, Ogun State, Nigeria. The metal cages were washed dried and sanitized before the animals were moved into them.

\section{Feed preparations and feeding regimes}

Ingredients that were used in the preparation of the diet is shown in Table 1 . The control diet had contained $80 \%$ of whole cassava root meal $\mathrm{T}_{0}$, while other three had $10 \%$ fermented soybean $\left(T_{1}\right)$, locust bean $\left(T_{2}\right)$ and fermented melon seed meal $\left(T_{3}\right)$. The level of crude protein was found to be different according to the treatments; while vitamins, minerals, palm kernel cake (PKC) and other ingredients had equal percentage of incorporation value within the treatment. The dietary treatments were designated as $T_{0}$ (control), $T_{1}, T_{2}$ and $\mathrm{T}_{3}$ and the trial continued for a period of 105 days.
Table 1. Composition of experimental diet fed to the animal

\begin{tabular}{lcccc}
\hline Ingredients (g) & $\mathrm{T}_{0}$ & $\mathrm{~T}_{1}$ & $\mathrm{~T}_{2}$ & $\mathrm{~T}_{3}$ \\
\hline Whole cassava meal & 80 & 70 & 70 & 70 \\
Fermented soybean & - & 10 & - & - \\
Fermented locust bean & - & - & 10 & - \\
Fermented melon & - & - & - & 10 \\
Palm kernel cake (PKC) & 15 & 15 & 15 & 15 \\
Bone meal & 2 & 2 & 2 & 2 \\
Urea & 2 & 2 & 2 & 2 \\
Salt & 0.5 & 0.5 & 0.5 & 0.5 \\
Vitamin premix & 0.5 & 0.5 & 0.5 & 0.5 \\
Total & 100 & 100 & 100 & 100 \\
\hline
\end{tabular}

The experimental diets used were made up of Elephant grass (Pennisetum purpureum) plus concentrate supplements. The concentrates were made up of fermented soybean, locust bean and melon seeds. The cassava which constituted the major bulk of the diets was washed to remove soil particles, milled andsundried on large tarpaulin sheets for 5 days before being incorporated into the diet. Soybean, locust bean and melon were purchased from the local market and were fermented, mixed with required additives transformed into pellet to carry out the experiment. Young succulent Elephant grass which was harvested and wilted for six hours was and was also fed to the animal sad libitum. Fresh water was made available all the times.

Elephant grass weighing $600 \mathrm{~g}$ was fed fed/head/day as the basal diet. The concentrate feed weighing 125gas pelleted ration (experimental diet) was fed per treatment per day every alternate days(after every single day). The daily feed consumption rates were estimated indirectly by the method of difference which involved subtracting the quantity of leftover from the measured earlier served to the animals at the beginning of each feeding day. The growth rate of the individual animals were measured once ina week following Morrison (2008). The morphometric measurement were carried out every 2 weeks and the average daily and weekly growth rates per treatment were calculated from the individual values. Anti-stress comprising of glucose solution was administrated during each weighing session as minimize stress.

\section{Management of experimental animals}

20Grasscutters (16 females and 4 males) 5-7 months old with an average body weight $717 \pm 21 \mathrm{~g}$ were used in the completely randomized design experiment that continued for a period of 15 weeks. Animals were divided into four treatments: each treatment included 4 females and 1 male and designatedas $T_{0}, T_{1}, T_{2}$ and $T_{3}$ groups. The experimental diets were fed to the animals accordingly for a period of fifteen weeks. Fresh clean water was provided ad libitum. Pelleted meal and cassava root meal were offered every morning. The feed refusal of the previous day's feeding were cleared out 
and weighed. The quantity of pelleted meal given was weighed daily into specially made ceramic feeding to minimize spillage and wastage. The animal was sanitized and quarantined to avoid ecto and endoparasites at the beginning of the experiment.

\section{Morphometric analyses}

The following linear body measurements were obtained in the morning before animals were offered forages:

- head length was measured from the base of neck to the tip of nose;

- body length was measured from the tip of the nose to the end of the tail;

- trunk length was measured from the tip of the nose to the attachment of the tail;

- heart girth was measured from the fore limb round the circumference of the chest;

- height at withers was measured from the fore limb to the back;

- fore limb was measured from the hitch bone to the claw; hind limb was measured from the pelvic bone to the feet;

- tail length was measured from the attachment of the tail to the end of tail;

- ear length was measured vertically within the ear while ear width was measured horizontally along the ear.

\section{Chemical Analysis}

The total daily faecal output was weighed for each animal and $25 \%$ of the sample were collected and stored in a freezer $\left(-4^{0} \mathrm{C}\right)$. These were bulked for each animal and dried in an oven at $105^{\circ} \mathrm{C}$ for 24hours to determine the dry matter (DM) contents. The sun dried and pulverized sample of Elephant grass blades, basal diets and faecal samples were analysed for proximate composition (AOAC, 2002). The ground sample of dried whole cassava root was also analysed. The total nitrogen in the feed was determined by macro Kjeldahl procedure (AOAC, 1995). Soxhlet extraction procedures were used to determine of ether extract. Gross energy content of the diets was estimated by adjabetic bomb calorimetry. Phytic acid was determined using the method of Buetler et al. (1980). Oxalic acid was determined using the precipitation method of AOAC (2002). Each animal was also weighed weekly. The feed conversion ratio (FCR) was calculated from records of average daily feed consumption and daily weight gain.

\section{Statistical Analysis}

Data were subjected to Analysis of variance (ANOVA) using (SAS, 2002) and mean comparison was performed with Duncan Multiple Range Test (DMRT).

\section{Results}

The results of chemical composition of the experimental diets with the basal diets, elephant grass ( $P$. purpureum) are shown in Table 2 . The level of crude protein differs between treatment groups, thus $\mathrm{T}_{1}$ was found to be greater than those of $T_{0}$, followed by $T_{3}$ and $T_{2}$ wasthe lowest percentage respectively. The result of the study revealed that the neutral detergent fibre (NDF) and the acid detergent fibre content of the experimental diets followed the same trend (Table 2). The value recorded in the chemical composition of diets were not significantly different $(\mathrm{P}>0.05)$. Thus, there were no significant $(\mathrm{P}>0.05)$ differences in the level of dry matter intake and ash content within the treatments. Energy content of the experimental diets indicates that $\mathrm{T}_{3}$ have the highest value recorded followed by $\mathrm{T}_{0}, \mathrm{~T}_{1}$ and $T_{2}$ has the lowest energy content. The differences in the value recorded for ash and ether extract showed similar difference among the treatment groups.

Table 2. Chemical Composition of concentrate and forage fed to experimental animals

\begin{tabular}{lccccc}
\hline Parameters & \multicolumn{4}{c}{ Concentrate Diets } & Elephant \\
\cline { 2 - 5 }$(\%)$ & $\mathrm{T}_{1}$ & $\mathrm{~T}_{2}$ & $\mathrm{~T}_{3}$ & $\mathrm{~T}_{4}$ & grass \\
\cline { 2 - 4 } Crude protein & 24.28 & 25.06 & 22.98 & 24.01 & 8.80 \\
Crude fibre & 8.35 & 8.16 & 8.52 & 8.25 & 15.15 \\
Ether extract & 11.75 & 10.69 & 11.32 & 12.04 & 6.67 \\
Ash & 11.20 & 10.82 & 11.38 & 10.84 & 3.99 \\
NFE & 44.42 & 45.27 & 43.80 & 44.86 & 65.39 \\
Energy & 1413.13 & 1324.53 & 1045.86 & 1421.11 & 509.63 \\
NDF & 75.61 & 78.32 & 74.66 & 79.45 & 61.36 \\
ADF & 31.62 & 33.44 & 32.16 & 35.48 & 25.67 \\
ADL & 12.38 & 14.81 & 14.22 & 12.98 & 9.69 \\
\hline
\end{tabular}

The performance of the Grasscutter is shown in Table 3 and the duration of the experiment was 15 weeks. There was significant difference $(\mathrm{P}<0.05)$ in average feed intake forage which treatment 3 carries the lowest value and the other treatment are similar in their value recorded. There was also significant difference $(\mathrm{P}<0.05)$ in average concentrate intake. The lowest total feed intake was observed in $T_{3}$. Total value for dry matter intake (DMI) indicate that animals in the $\mathrm{T}_{2}$ consumed less feed $(\mathrm{P}>0.05)$ within the treatment. There were significant $(\mathrm{P}<0.05)$ differences in the level of dry matter concentrate in $T_{1}$, which has the highest value compared to $T_{3}$, followed by $T_{0}$ and $T_{2}$ having the lowest value of the feed concentrate. Weight gain was lower $(\mathrm{P}>0.05)$ in treatment 3 compared to the animal on the $T_{0}, T_{1}$ and $T_{2}$ respectively. While $T_{1}$ had highest weight gain within the experiment accordingly, there were significant $(\mathrm{P}<0.05)$ difference in feeding conversion ratio in the treatment. 
Table 3. Production performance of cane rat fed the experimental diets

\begin{tabular}{lccccc}
\hline Parameters & $\mathrm{T}_{0}$ & $\mathrm{~T}_{1}$ & $\mathrm{~T}_{2}$ & $\mathrm{~T}_{3}$ & SEM \\
\hline Duration of experiment (weeks) & 15 & 15 & 15 & 15 & \\
Average feed intake forage (g) & $297.37^{\mathrm{a}}$ & $302.3^{\mathrm{a}}$ & $295.41^{\mathrm{a}}$ & $274.16 \mathrm{~b}$ & 27.02 \\
Average feed intake conc. (g) & $76.51^{\mathrm{b}}$ & $78.57^{\mathrm{a}}$ & $74.84^{\mathrm{c}}$ & $76.89 \mathrm{~b}$ & 1.65 \\
Total feed intake (g) & $373.88^{\mathrm{b}}$ & $380.95^{\mathrm{a}}$ & $370.25^{\mathrm{b}}$ & $351.05^{\mathrm{c}}$ & 5.19 \\
Dry matter forage (g) & $105.55^{\mathrm{a}}$ & $101.41^{\mathrm{a}}$ & $99.08^{\mathrm{a}}$ & $91.95^{\mathrm{b}}$ & 5.17 \\
Dry matter concentrate (g) & $59.23^{\mathrm{a}}$ & $67.51^{\mathrm{a}}$ & $53.39^{\mathrm{b}}$ & $66.90^{\mathrm{a}}$ & 3.89 \\
Total dry matter (g) & $164.78^{\mathrm{a}}$ & $168.92^{\mathrm{a}}$ & $152.47^{\mathrm{c}}$ & $158.85^{\mathrm{b}}$ & 3.01 \\
Initial live weight (g) & $694^{\mathrm{a}}$ & $730^{\mathrm{a}}$ & $708^{\mathrm{a}}$ & $736^{\mathrm{a}}$ & 42.07 \\
Final live weight (g) & $1175^{\mathrm{a}}$ & $1266.7^{\mathrm{a}}$ & $1215^{\mathrm{a}}$ & $1143^{\mathrm{a}}$ & 51.55 \\
Weight gain (g) & $481^{\mathrm{ab}}$ & $536.7^{\mathrm{a}}$ & $507^{\mathrm{b}}$ & $407^{\mathrm{c}}$ & 39.55 \\
Daily weight gain (g/head/day) & $4.51^{\mathrm{b}}$ & $5.11^{\mathrm{a}}$ & $4.83^{\mathrm{ab}}$ & $3.88^{\mathrm{c}}$ & 0.28 \\
Feed conversion ratio & $1.29^{\mathrm{b}}$ & $1.41^{\mathrm{a}}$ & $1.36^{\mathrm{ab}}$ & $1.16^{\mathrm{c}}$ & 0.07 \\
\hline
\end{tabular}

${ }^{\mathrm{abc}}$ mean within a row with unlike superscript letters were significantly different $(\mathrm{P}<0.05)$. For details of diets and procedure, see Table 1.

The physical body measurement of the Grasscutter within the treatment is shown in Table $4 . T_{1}$ have the higher weight gain when compared to those of other treatments. There were no significant $(\mathrm{P}>0.05)$ differences in head, body and tail length within the treatments. However, there were significant differences $(\mathrm{P}<0.05)$ in the trunk length of $\mathrm{T}_{1}$ over $\mathrm{T}_{2}, \mathrm{~T}_{0}$ and $\mathrm{T}_{3}$. No significant differences $(\mathrm{P}<0.05)$ were observed in the height at withers and fore limbs within the treatment. On the other hand, significant difference $(\mathrm{P}<0.05)$ were foundin ear width within the treatment. $\mathrm{T}_{2}$ which had the highest value followed by $\mathrm{T}_{1}, \mathrm{~T}_{3}$ and $\mathrm{T}_{0}$.

Table 4. Physical body measurement of Grasscutter fed experimental diets

\begin{tabular}{lccccc}
\hline Parameters & $\mathrm{T}_{0}$ & $\mathrm{~T}_{1}$ & $\mathrm{~T}_{2}$ & $\mathrm{~T}_{3}$ & $\mathrm{SEM}$ \\
\hline $\begin{array}{l}\text { Duration of experiment } \\
\text { (days) }\end{array}$ & 105 & 105 & 105 & 105 & \\
Body weight gain (g) & $481^{\mathrm{ab}}$ & $536.7^{\mathrm{a}}$ & $507^{\mathrm{b}}$ & $407^{\mathrm{c}}$ & 214.4 \\
Head length (cm) & $1.08^{\mathrm{a}}$ & $0.16^{\mathrm{c}}$ & $0.96^{\mathrm{a}}$ & $0.46^{\mathrm{b}}$ & 0.04 \\
Body length (cm) & 5.50 & 5.56 & 5.42 & 4.81 & 1.11 \\
Trunk length (cm) & $4.55^{\mathrm{b}}$ & $4.78^{\mathrm{a}}$ & $4.56^{\mathrm{ab}}$ & $4.12^{\mathrm{a}}$ & 0.19 \\
Tail length (cm) & 0.75 & 1.02 & 1.82 & 1.48 & 0.07 \\
Heart girth (cm) & $2.17^{\mathrm{a}}$ & $2.94 \mathrm{~b}$ & $5.00^{\mathrm{ab}}$ & $4.60^{\mathrm{ab}}$ & 0.98 \\
Height at withers (cm) & 2.35 & 1.42 & 2.46 & 2.61 & 0.16 \\
Fore limb (cm) & 2.80 & 1.43 & 2.06 & 3.16 & 0.27 \\
Hind limb (cm) & $1.37^{\mathrm{a}}$ & $0.98^{\mathrm{b}}$ & $1.24^{\mathrm{a}}$ & $1.19^{\mathrm{a}}$ & 0.06 \\
Ear length (cm) & 0.10 & 0.10 & 0.14 & 0.17 & 0.01 \\
Ear width (cm) & $0.10^{\mathrm{a}}$ & $0.16^{\mathrm{a}}$ & $0.22^{\mathrm{b}}$ & $0.11^{\mathrm{a}}$ & 0.01 \\
\hline
\end{tabular}

${ }_{\mathrm{abc}}$ mean within a row with unlike superscript letters were significantly different $(\mathrm{P}<0.05)$. For details of diets and procedure, see Table 1.

The mean for the nutrient digestibility of the experimental diets were shown in Table 5. The percentage crude protein were significant differences $(\mathrm{P}<0.05)$ among the treatment groups. $\mathrm{T}_{2}$ have had highest value of 10.03 which made the feed more nutritious and supported the growth of animals. The value recorded for ether extract, energy and acid detergent fibres showed significant difference $(\mathrm{P}<0.05)$ with the treatment in which $\mathrm{T}_{1}>\mathrm{T}_{2}>\mathrm{T}_{3}>\mathrm{T}_{0}$ respectively. The levels of crude fibre with the treatment were significantly different and $\mathrm{T} 1$ had the highest value while lowest value for crude fibre was recorded from $\mathrm{T}_{2}$.
However, there was significant difference in the level of ash and acid detergent fibre content; $T_{0}$ had the highest percentage value within the treatments. The energy content of the experimental diets was higher in $T_{1}$ which was considered to be significantly different $(\mathrm{P}<0.05)$ within the treatment and the lowest energy value was recorded from $T_{3}$. The highest acid detergent fibre was found in $\mathrm{T}_{0}$ that made it significant within the treatment.

Table 5. Nutrient digestibility of Grasscutter fed experimental diets

\begin{tabular}{lccccc}
\hline Parameters (\%) & $\mathrm{T}_{0}$ & $\mathrm{~T}_{1}$ & $\mathrm{~T}_{2}$ & $\mathrm{~T}_{3}$ & SEM \\
\hline Crude protein & $8.29^{\mathrm{c}}$ & $10.03^{\mathrm{a}}$ & $9.16^{\mathrm{b}}$ & $8.59^{\mathrm{bc}}$ & 0.81 \\
Crude fibre & 7.06 & 8.84 & 6.84 & 7.20 & 0.62 \\
Ether extract & $8.56^{\mathrm{c}}$ & $11.13^{\mathrm{a}}$ & $9.28^{\mathrm{b}}$ & $9.10^{\mathrm{bc}}$ & 0.71 \\
Ash & $7.83^{\mathrm{a}}$ & $8.04^{\mathrm{a}}$ & $6.99^{\mathrm{c}}$ & $7.21^{\mathrm{b}}$ & 0.23 \\
NFE & $81.81^{\mathrm{c}}$ & $89.43^{\mathrm{a}}$ & $84.17^{\mathrm{b}}$ & $63.11^{\mathrm{d}}$ & 2.33 \\
NDF & $54.02^{\mathrm{b}}$ & $59.11^{\mathrm{a}}$ & $56.42^{\mathrm{b}}$ & $46.16^{\mathrm{c}}$ & 2.57 \\
ADF & $34.97^{\mathrm{a}}$ & $32.67^{\mathrm{b}}$ & $29.04^{\mathrm{c}}$ & $31.79^{\mathrm{b}}$ & 2.27 \\
ADL & $11.30^{\mathrm{c}}$ & $19.21^{\mathrm{a}}$ & $14.14^{\mathrm{b}}$ & $10.93^{\mathrm{c}}$ & 2.81 \\
\hline
\end{tabular}

${ }^{\text {abcd }}$ mean within a row with unlike superscript letters were significantly different $(\mathrm{P}<0.05)$. For details of diets and procedure, see Table 1.

\section{Discussion}

The chemical composition of the experimental diets compared favorably with the recommended diets found in literature. The level of acid detergent fibre in the treatment diets was found to be higher than the 13-17\% level recommended by Pound et. al.,(1995). While neutral detergent fibre level should be within the range of 42-74\% Mensah and Okeyo (2005) for adult cane rat. The present results have shown that Grasscutter may not grow well when fed acid detergent fibre beyond $17 \%$.The crude protein levels of the four diets were higher than the minimum of $17 \%$ suggested by Pound et. al.(1995), for herbivores in captivity. The energy content in $T_{3}$ wasslightly higher as compared to those of $T_{0}, T_{2}$ and $\mathrm{T}_{1}$ which had the least value. The metabolisable energy (ME) value of the four experimental diets was high enough to support at least a moderate growth rate as seen in the literature. The chemical contents of the 
diets, therefore, appeared to be optimum to support a reasonable since all the experimental animals gained weight over the period of 15 weeks survived the experimental period.

The current dry matter intake was greater than the 89$124 \mathrm{~g}$ for forage with the range of 31-65g reported earlier by Mensah, (2000). But this may be due to the fact that the earlier researchers fed forage only and it may be mentioned here that Grasscutters may not require to eat much if they are supplied with feed which well balanced in energy and other nutrients. The value for dry matter intake (DMI) showed that the animals in $\mathrm{T}_{2}$ consumed less of the concentrate diets. Furthermore, the crude fibre of the experimental diets was all lower than 25$45 \%$ that was recommended for adult Grasscutter (Mensah, 1993, 1995). The present experiments have shown that with the same level of feeding, there was no significant difference in the mean final weights $(\mathrm{P}<0.05)$. Although there was significant difference in the value recorded in the final weights in animal supplied diet $\mathrm{T}_{1}$ which had the highest weight gain than the corresponding $\mathrm{T}_{3}, \mathrm{~T}_{2}$ and $\mathrm{T}_{0}$.

Consumption of feed always affected by the level of crude fibre of the feed. However, no significant difference $(\mathrm{P}>0.05)$ was observed in the mean total weights of the Grasscutter. The highest total mean weight gain was recorded for Grasscutter fed with whole cassava root meal combined with fermented soybean meal, followed by whole cassava meal combined with fermented locust bean, closely followed by whole cassava meal combined with fermented melon and lastly followed by whole cassava meal.

There was a higher feed intake in $T_{1}$ in the experiment compared to those in $T_{0}, T_{2}$ and $T_{3}$. Animals in $T_{1}$ had an average intake but rather have a lower average total weight gain as opposed to those of other animals on the treatment. This could be explained by the fact that animals on $T_{1}$ (whole cassava root meal combined with fermented soybean meal) had the highest feed intake and the nutritional quality of their feed was also very high. These were in agreement with the report of Onyeanusi and Famoyin (2005) who found that cassava is superior to other sources of carbohydrate particularly when fed along with balanced protein sources.

The morphometric results showed that animals within the treatment gained most weight in their trunk which made them to shrink and stretch. Little differences were however, observed in tail, head, fore limb, hind limb, ear length and ear width respectively. By and large, when fed whole cassava root meal combined with fermented soybean meal to the Grasscutters were found to be more efficient to convert feed into muscle, when compared with the other treatments.

\section{Conclusion}

The whole cassava root combined with fermented soybeans meal supported high growth rate than other treatments- used during this study. It is therefore recommended that the whole cassava root combined with fermented soybeans meal could be used as complete diets for sustainable Grasscutter production. However, further work on the mineral excretion and use of phytase enzymes to maximize absorption of essential and trace minerals from feeding cassava root combined with fermented soybeans meal may be required.

\section{Acknowledgement/Funding}

Self-sponsor project

\section{References}

Adu, E.K. 2005. Constraints to grass-cutter production in Ghana. Proc. of the Int'l forum on grass-cutter. Institute of Local Government Studies. Accra. Ghana, Ministry of Food and Agriculture. Accra. Ghana. 44-50.

Akpan I.A., Wogar, G.S.I., Effiong, O.O. and Akpanenua, E.J. 2009. Growth performance of grass cutter fed diets treated with urea and urine solution. Proc. of 34th Ann. Conf. of Nig. Soc.For Anim. Uyo, Nigeria.163-164.

AOAC, 1995. Official of analysis Association of analytical chemistry official method of analysis.16th edition Washington D.C. USA.

AOAC, 2002.Official of analysis Association of analytical chemistry official method of analysis.18th edition Washington D.C. USA.

Ayodele, I.A. and Meduna, A.J. 2007.Essentials of Grasscutter Farming. Hope Publications, Ibadan, Nigeria. Pp. 37 BBC News. Scientist find new strain of HIV. 2 August 2009.

Buetler, H.J., Becker, G., Michael, and Watter, E. 1980. "Rapid Method for the determination of oxalate" Fresenius J Anal Chem., 301: 186-187.

Cocolin, L. and Ercolini, 2009. Microbiology of food fermentation: the support of molecular techniques In: Scitopic (Research summary by experts).

Eniolorunda, O.O. and Olamilusi, O.D. 2016. Effect of whole cassava root and yam tubers on performance of grasscutter (Thyronomus swindarianus) held in captivity. Assiut J. Agric. Sci., (47) No. (4): 119-123

Ewer, R.D. 1969. Form and function in the grasscutter (Thryonomys swinderianus). Temm (Rodentia, Thryonomyidae). Ghana J. Sci., 9: 31-149.

Henry A.J., Njume G.N. 2008. Effect of varied energy levels on the carcass characteristics of grasscutter (Thryonomys swinderianus). Proc. Of 33rd Ann. Conf. of the Nig. Soc. For Anim. Prod. Ayetoro, Ogun State, Nigeria.168-170.

Kusi C., Tuah A.K., Annor, S.Y., Djang-Fordjour, K.T. 2012. Determination of dietary crude protein level required for optimum growth of the grasscutter in captivity. Livestock Res. For Rural Devt.24 (10).

Meduna, A.J. 2002. Preliminary observation on cane rat (Thryonomys swinderianus, Temminck) feeding and breeding. Proc. Of the 27th Ann. Conf of the Nig. Soc. For Anim. Prod. Federal College of Tech., Akure. pp 304-305.

Mensah G.A., Okeyo, A.M. 2005. Continued harvest of the divers African animal genetic resources from the wild through domestication as a strategy for sustainable use: A case of the larger grass-cutter (Thryonomys swinderianus). International Livestock Research Institute. Available:http// agtr.ilri.cigar.org/Casestudy/Mensah/Mensah.htm.

Mensah, G.A. 1993. Futteraufnahme und Verdaulichkeitbeim Grasnager (Thryonomys swinderianus). Thèse de Doctorat, Institut 480, Université de Hohenheim, Allemagne. 107.

Mensah, G.A. 1995. Consommation et digestibilitéalimentaire chez l'aulacodeThryonomys swinderianus. Tropicultura. 13(3): 123-124. 
Morrison, F.B. 2008. A symposium on the way of comparing the practical nutritive values of feeds: determining net energy values by means of feeding experiments. J. Anim. Sci., 1937: 12-20

National Research Council, 1991.Grasscutter In micro livestock: Little-Known small Animals with a promising Economic Future. National Academy Press, Washington, D. C (USA), p.233-240.

Obi, O.O., Omole, A.J., Ajasin, F.O. and Tewe, O.O. 2009. Comparative evaluation of growing Grasscutter fed pelletized or unpelletized feed. Moor Journal of Agric. Res. (Accepted article).

Onakomaiya, S.O., Oyesiku, K.A, and Jegede, S.J. 1992. Ogun State in Maps. First ed. Rex. Charles publication, Ibadan, Nigeria.
Onyeanusi, A.E. and Famoyin, J.B. 2005. Health care management of grasscutters in captivity; Assessment of causes of mortalities among rearing livestock in Ibadan metropolis. Journal of forestry and management.2, pp56-58.

Pound, W.G., Church, D.C. and Pond, K.R. 1995 Basic animal nutrition and feeding 4 Edn. John Wileyth and sons, Inc., Ontario, pp: 565-573. 12

SAS, Statistical Analysis Institute, 2002. Users Guide. Statistical Analysis Institute, Inc, Carry North Caroline, USA.

Schrage R. and Yewandan, L.T. 1995. Summary of grasscutter farming. German Society for Technical Cooperation (GTZ BMZ), Allemagne Gmbtt, pp 103. 